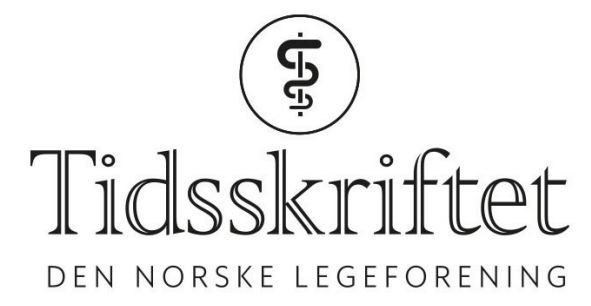

\title{
Meldte dødsfall
}

MELDTE DØDSFALL

Knut Gjelland 18.4.1942-4.9. 2014

Witold Jacewicz 3.8. 1952-28.8. 2014

Hjalmar B. Kvåle 27.9. 1928-8.9. 2014

Asbjørn Langslet 8.1. 1939-8.8. 2014

Finn Ræder 11.8. 1933-30.8. 2014

Pål Anton Skagseth 27.6.1929-5.6. 2014

Håkon Thorkelsen 11.2. 1925-11.8. 2014

Knut Zapffe 1.6. 1940-28.8. 2014

Publisert: 28. oktober 2014. Tidsskr Nor Legeforen. DOI: 10.4045/tidsskr.14.1133

Redaktør: .

(C) Tidsskrift for Den norske legeforening 2020. Lastet ned fra tidsskriftet.no 